\title{
Hyperglycemia-Induced Hyperinsulinemia Decreases Maternal and Fetal Plasma Protein C Concentration during Ovine Gestation
}

\author{
MARILYN J. MANCO-JOHNSON, THOMAS CARVER, LINDA J. JACOBSON, \\ SUSAN F. TOWNSEND, AND WILLIAM W. HAY, JR. \\ Department of Pediatrics and the Division of Perinatal Medicine, University of Colorado Health \\ Sciences Center, Denver, Colorado 80262
} \begin{abstract}
ABST
To determine effects of diabetic gestation on plasma
concentration of the coagulation regulatory protein, protein $\mathrm{C}$, pregnant ewes were given glucose infusions to raise plasma glucose to twice baseline concentration or insulin infusions to lower glucose concentration to half baseline value. Control animals received no infusions. Concentrations of protein $S$, factor $X$, and antithrombin III were determined for comparison. Concentrations of glucose, insulin, and those above were determined thrice weekly for 2-9 wk. Short-term (8-12 h) infusions of glucose or insulin were performed to isolate their effects on concentration of protein C. Results were analyzed using a two-tailed $t$ test, and protein $\mathrm{C}$ concentrations were further analyzed using a full linear mixed-effects model. In long-term infusions, hyperglycemia-induced hyperinsulinemia (mean insulin concentration $141 \mu \mathrm{U} / \mathrm{mL}$ ) exerted negative effects on maternal concentrations of protein $\mathrm{C}[0.69 \mathrm{U} / \mathrm{mL}, n$ (number of samples) $=32$, experimental versus $0.97 \mathrm{U} / \mathrm{mL}, n=157$, control], protein $\mathrm{S}(0.86 \mathrm{U} / \mathrm{mL}, n=31$, experimental versus $1.04 \mathrm{U} / \mathrm{mL}, n=109$, control $)$, and factor $\mathrm{X}(0.89 \mathrm{U} / \mathrm{mL}$, $n=31$, experimental versus $1.08 \mathrm{U} / \mathrm{mL}, n=109$, control); it exerted no effects on antithrombin III $(1.05 \mathrm{U} / \mathrm{mL}, n=$ 23 , experimental versus $1.04 \mathrm{U} / \mathrm{mL}, n=32$, control). The fetal lamb did not respond to chronic moderate hyperglycemia (mean $33 \mathrm{mg} / \mathrm{dL}$ ) with a consistent change in insulin
\end{abstract}

concentration (mean 10 versus $9 \mu \mathrm{U} / \mathrm{mL}$ ): no coagulation protein changed. In contrast, fetal hypoglycemia resulted in decreased fetal plasma insulin $(5 \mu \mathrm{U} / \mathrm{mL}$ versus $10 \mu \mathrm{U} /$ $\mathrm{mL})$ and a corresponding increase in protein $\mathrm{C}(\mathrm{O} .56$ $\mathrm{U} / \mathrm{mL}, n=17$, experimental, versus $0.48 \mathrm{U} / \mathrm{mL}, n=180$, control) protein $\mathrm{S}(0.65 \mathrm{U} / \mathrm{mL}, n=17$, experimental versus $0.44 \mathrm{U} / \mathrm{mL}, n=87$, control $),$ factor $\mathrm{X}(0.31 \mathrm{U} / \mathrm{mL}, n=16$, experimental versus $0.24 \mathrm{U} / \mathrm{mL}, n=86$, control), and antithrombin III $(0.96 \mathrm{U} / \mathrm{mL}, n=14$, experimental versus $0.84 \mathrm{U} / \mathrm{mL}, n=32$, control). Insulin concentration varied inversely with protein $\mathrm{C}$ concentration when all groups were considered together and accounted for $12 \%$ of the variability of protein $\mathrm{C}$ concentration in control ewes. Glucose was not found to exert an independent effect on protein $\mathrm{C}$ concentration within any study group but was significant when all groups were considered together. Short-term studies confirmed the long-term infusion findings in the maternal group with hyperglycemia-induced hyperinsulinemia. These studies indicate that hyperglycemia-induced hyperinsulinemia may predispose to hypercoagulability and thrombosis in the diabetic ewe and her fetus. (Pediatr Res 36: 293-299, 1994)

AT-III, antithrombin III
Infants of diabetic mothers have an increased incidence of large vessel thromboses during the neonatal period. Oppenheimer and Esterly (1) reported a $15 \%$ rate of neonatal thromboses in infants of diabetic mothers in contrast to $0.8 \%$ in nondiabetic infants. Many of these thromboses appear to originate in utero based on histologic study. The etiology of this hypercoagulability is not

Received March 23, 1993; accepted March 27, 1994.

Correspondence: Marilyn J. Manco-Johnson, University of Colorado Health Sciences Center, Box C-220, 4200 East 9th Ave., Denver, CO 80262.

Supported by the following grants: National Institutes of Health, HL 44586, and the American Diabetes Association (M.M.J.); and National Institutes of Health, DK 35836 (W.W.H.). known. Our previous work revealed an increased incidence of severe protein $C$ deficiency in term and nearterm infants of diabetic mothers with plasma concentrations less than one fourth the normal mean concentration for age (2). This neonatal deficiency state appeared to be an independent risk factor for thrombosis.

Protein C is a vitamin K-dependent coagulation protein that appears to serve a pivotal role in the regulation of coagulation (3). When thrombin is generated, it forms a complex with an endothelial cell glycoprotein, thrombomodulin, which inhibits the procoagulant properties of thrombin and forms a potent activator for plasma protein C. Activated protein $\mathrm{C}$ inactivates the coagulation cofac- 
tors, factor $\mathrm{Va}$ and factor VIIIa, effectively dampening the rate of further thrombin formation. The function of activated protein $\mathrm{C}$ is greatly accelerated by formation of a complex on the platelet and endothelial cell surface with its cofactor protein S. A second cofactor for activated protein $C$ has been newly described $(4,5)$. Infants with severe genetic deficiencies of protein $\mathrm{C}$ may develop thromboses of the retinal, cerebral, and renal arteries in utero and regularly develop severe disseminated intravascular coagulation and thrombosis shortly after birth (6). A single infant who presented with severe protein $S$ deficiency in the neonatal period had disseminated intravascular coagulation similar to that of infants with severe protein $\mathrm{C}$ deficiency (7). Healthy human neonates have plasma concentrations of protein $\mathrm{C}$ that are approximately $40 \%$ of normal adult at term birth (6). Plasma concentrations of protein $\mathrm{C}$ have not been determined in fetuses during normal or diabetic human gestation.

To study the development of protein $\mathrm{C}$ during diabetic gestation, we used a chronically catheterized pregnant sheep model. We chose the pregnant sheep because Kisker et al. (8), Massicotte et al. (9), and Moalic et al. (10) previously showed that maturation of coagulation factors in the fetal lamb is similar to that of humans. In addition, one of the authors has observed increased catheter-related thromboses and occlusions in adult (maternal) and fetal sheep with chronic glucose and insulin infusions (W. W. Hay Jr, unpublished observations).

The studies were divided into two parts. First, pregnant sheep were made chronically hyperglycemic, hyperinsulinemic, or both with continuous infusions of glucose or insulin to detect an effect of glucose or insulin on plasma protein $\mathrm{C}$ concentration. Other coagulation factors were assayed to determine more general effects of hyperglycemia and hyperinsulinemia on plasma coagulation protein concentrations including protein $S$, a vitamin $\mathrm{K}$-dependent cofactor for protein C; factor $\mathrm{X}$, a vitamin $\mathrm{K}$-dependent procoagulant protein whose plasma disappearance time is similar to that of protein S; and AT-III, a vitamin $\mathrm{K}$-independent coagulation inhibitory protein. Next, short-term (8-24 h) infusion studies were performed to isolate the effects of glucose and insulin on plasma protein $\mathrm{C}$ concentration and to examine the time of onset and duration of the effect. The duration of the short-term infusion studies was chosen to include 2 halflives of protein C, based on human data (11).

\section{METHODS}

\section{Preparation of the Animal Model}

Columbia-Rambouillet pregnant sheep with known gestational age were operated on between 70 and $80 \mathrm{~d}$ gestation to place maternal arterial sampling and venous infusion catheters or at approximately $120 \mathrm{~d}$ gestation for placement of both maternal and fetal arterial sampling catheters and venous infusion catheters. At both gestations, surgery was performed using either of two anesthesia protocols: i.v. pentobarbital sedation $(15 \mathrm{mg} / \mathrm{kg})$ and spinal anesthesia (tetracaine $\mathrm{HCl}, 10 \mathrm{mg}$ in hypertonic glucose) or intramuscular acetylpromazine $(1 \mathrm{mg} /$ $\mathrm{kg}$ ) with i.v. ketamine anesthesia (12-15 ng/kg loading dose with $0.3-0.5 \mathrm{mg} / \mathrm{kg} / \mathrm{min}$ continuous infusion). Maternal sampling catheters were placed into a maternal femoral vein and artery; fetal catheters were placed into the abdominal aorta and a femoral vein as previously described (12-15). All catheters were tunneled subcutaneously and kept within a plastic pouch attached to the maternal flank. The catheters were flushed daily to every other day with $0.9 \% \mathrm{wt} / \mathrm{vol} \mathrm{NaCl}$ in $\mathrm{H}_{2} 0$ that contained 30 $\mathrm{U} / \mathrm{mL}$ heparin. After surgery, the sheep were allowed to recover at least $4 \mathrm{~d}$ before study. All protocols were approved by the Animal Care and Use Committee of the University of Colorado Health Sciences Center.

\section{Laboratory Methods}

A 1.2-mL sample of blood was drawn from the indwelling maternal and fetal arterial catheters into EDTA-lined syringes for assay of plasma insulin and glucose concentrations, $0.6 \mathrm{~mL}$ of arterial blood were drawn into glass capillary tubes lined with heparin for measurement of oxygen saturation, and $0.9 \mathrm{~mL}$ of arterial blood were drawn into $0.1 \mathrm{~mL}$ of $3.8 \%$ sodium citrate for assay of protein $\mathrm{C}$, protein $\mathrm{S}$, factor $\mathrm{X}$, and AT-III.

Plasma insulin concentrations were determined using an RIA (Ventrex Laboratories, Inc., Portland, ME or Binax, Inc., S. Portland, ME) and ovine insulin standards (generously provided by Eli Lily Co., Indianapolis, IN) as previously described $(12,13)$. Methods for determining glucose concentration by a Yellow Springs glucose analyzer (Yellow Springs Instrument Co., Yellow Springs, $\mathrm{OH}$ ) and oxygen saturation using an OSM 3 hemoximeter have previously been described $(13,14)$.

Protein $\mathrm{C}$ was purified from ovine plasma using barium chloride precipitation, EDTA elution, ammonium precipitation, and sequential chromatographies over DEAE Sepharose, heparin Sepharose, and Blue Sepharose CL-6B (M. J. Manco-Johnson, unpublished data). Protein purification was monitored using migration on SDSPAGE as well as functional assays. Protein $C$ was monitored with activation using the snake venom agkistrobon contortrix and detection with chromogenic substrate S2366. Vitamin K-dependent coagulation proteins, protein $\mathrm{S}$ and factor $\mathrm{X}$, were isolated using similar techniques. Protein $S$ eluted from DEAE Sepharose fast flow in fractions 60-87 along with factor IX and factor VII. These fractions were pooled and applied to Blue Sepharose CL-6B. Protein S eluted in fractions 75-90 as a single protein with characteristic doublet migration on reduced SDS-PAGE at $85 \mathrm{kD}$ and lacking activity for factors II, VII, IX, and X and protein C. This protein prolonged the activated partial thromboplastin time of ovine plasma enriched with activated protein $\mathrm{C}$. Factor $\mathrm{X}$ eluted from the DEAE Sepharose fast flow in fractions $110-125$ as a single protein with factor $\mathrm{X}$ activity on a one-stage clotting assay using human deficient substrate. The proteins 
were used to immunize New Zealand White rabbits for production of polyclonal antibodies. The resultant antibodies to protein $\mathrm{S}$ and factor $\mathrm{X}$ were partially purified and used in Laurell rocket assay. AT-III was assayed chromogenically using the Coamate AT-III kit (Kabi, Piscataway, NJ).

Normal values for ovine protein $\mathrm{C}$, protein $\mathrm{S}$, factor $\mathrm{X}$, and AT-III were derived from plasma obtained from 26 healthy nonpregnant adult sheep. A standard ovine pool was prepared from these individual plasma samples. Results of these coagulation assays in the control, hyperglycemic, and hypoglycemic ewes and fetuses were evaluated over gestation to determine physiologic changes associated with gestation.

\section{Animal Protocols}

Models of long-term maternal hyperglycemia and hyperinsulinemia. To investigate the effects of chronic hyperglycemia, hyperinsulinemia, or both during gestation, pregnant ewes were continuously infused with glucose or insulin. No fetus was directly infused for the long-term studies; fetuses were made passively hyperglycemic or hypoglycemic from the maternal glucose concentration. For hyperglycemic studies, maternal and fetal catheters were placed at $70 \mathrm{~d}$ gestation; fetal catheters were placed at about $120 \mathrm{~d}$ gestation, precluding a baseline fetal sample. Ewes were allowed ad libitum water and food (alfalfa pellets) intake for the duration of the studies. Arterial blood samples were drawn three times weekly and assayed for insulin, glucose, and concentration of the coagulation proteins described above.

Animals were randomly assigned to three groups. Ten ewes were made chronically hyperglycemia by continuous infusion of glucose (dextrose $50 \% \mathrm{wt} / \mathrm{vol}$ in $\mathrm{H}_{2} \mathrm{O}$, approximately $4 \mathrm{mg} / \mathrm{min} / \mathrm{kg}$ ) sufficient to raise the plasma glucose concentration to a mean concentration twice the baseline concentration. Samples were collected from these 10 ewes and eight of their fetuses. Eight ewes were made chronically hyperinsulinemic by continuous infusion of insulin (a mean of $1.0 \mathrm{mU} / \mathrm{min} / \mathrm{kg}$ maternal weight, range $0.5-4)$ sufficient to lower plasma glucose concentration to a mean value half of the baseline value. Samples were collected from six fetuses of hyperinsulinemic ewes, but baseline fetal samples were not available. The infusions were continued for a mean of $4.2 \mathrm{wk}$ (range 2-9 wk).

Eighteen control ewes that were matched with the study ewes for time from conception underwent similar catheter placements and blood sampling procedures, but nothing was infused through the catheters except for flushes $(1.0 \mathrm{~mL})$ of heparinized saline once daily to every other day. Plasma concentrations of protein C, protein S, factor X, antithrombin III, insulin, and glucose were measured in control animals as for the experimental infusion groups.

Models of short-term hyperglycemia and hyperinsulinemia. In these experiments, protein C was the only coagulation protein assayed, because the long-term infusion studies suggested that hyperglycemia, hyperinsulinemia, or both exerted a unique or most pronounced effect on protein $\mathrm{C}$. Therefore, the timing of specimen collection in the short-term infusions was calculated to accommodate the rapid plasma disappearance time of protein $\mathrm{C}$ and was not appropriate to study the other coagulation proteins.

To isolate the effects of glucose and insulin, short-term studies were conducted with glucose/insulin clamps. Study groups included hyperinsulinemic/euglycemic, hyperglycemic/euinsulinemic, hyperinsulinemic/hyperglycemic, and euglycemic/euinsulinemic conditions. Food was removed from the ewe at the onset of study but water was available ad libitum. For most studies, both the ewe and fetus were infused for $8 \mathrm{~h}$, although one to two maternal/fetal pairs in each study group were studied for $24 \mathrm{~h}$ to determine the duration of the observed effects. Two to three baseline samples for plasma glucose, insulin, and protein $C$ were obtained at 5-min intervals. After starting the glucose or insulin infusions, blood glucose concentrations were determined every $20 \mathrm{~min}$ or more frequently as needed to maintain glucose concentrations within $7 \%$ of baseline values $(12,13)$. Blood for assay of plasma protein $\mathrm{C}$, glucose, and insulin concentrations was obtained hourly; blood for oxygen saturation was obtained at baseline, at $4 \mathrm{~h}$, and at completion of the study. Two fetuses could not be studied because of catheter malfunction.

In the hyperinsulinemic/euglycemic group, eight pregnant ewes and seven fetuses were given continuous i.v. infusions of insulin at $1 \mathrm{mU} / \mathrm{kg} / \mathrm{min}$. A glucose clamp was used to maintain euglycemia $(12,13)$. In the hyperglycemic/eusinsulinemic group, two ewes and two fetuses were given i.v. infusions of somatostatin (Sandostatin, Sandoz Pharmaceuticals Corp., East Hanover, NJ) at $4-10 \mu \mathrm{g} / \mathrm{kg} / \mathrm{h}$ to suppress insulin secretion. They then received glucose infusions to raise glucose concentrations to twice baseline levels. In the hyperglycemic/ hyperinsulinemic group, seven pregnant ewes and eight fetuses were given glucose (dextrose) infusions to maintain plasma glucose at approximately 2 times baseline, while no attempt was made to control insulin concentration. There were two control groups. One control group of five ewes and five fetuses was given infusions of somatostatin alone to suppress insulin release with no glucose infusion. A second control group of five ewes and seven fetuses was given infusions of saline $(0.9 \% \mathrm{NaCl}$ $\mathrm{wt} / \mathrm{vol}$ in $\mathrm{H}_{2} \mathrm{O}$ ) in a volume equal to the glucose infusions. In both control groups, blood sample timing and volumes were equal to those in the experimental groups. Results in the two control groups were identical. They were thereafter analyzed together.

\section{Data Analysis}

Long-term model. In the long-term model, plasma concentrations of protein $\mathrm{C}$, protein S, factor X, AT-III, glucose, and insulin were compared among the three study groups. Effects of plasma glucose and insulin con- 
centration on plasma concentration of the coagulation proteins were determined using standard two-tailed $t$ test. Because results of protein $\mathrm{C}$ were most marked in these analyses, the protein $\mathrm{C}$ data was further subjected to linear mixed-effects models to account for both the multiple measurements made in study subjects over time as well as potential competing effects of glucose, insulin, and duration of study (16). Using these models, data analyses were performed within each study group and also by using the combined subjects as one group.

Short-term model. The short-term infusions were analyzed by plotting the mean protein $\mathrm{C}$ concentration at each time point $( \pm 1$ SD) for each of the four study groups. The relationships for the fetal and maternal data were plotted separately. Group means were tested for differences using an analysis of variance technique that accounts for both variability among different sheep and among multiple measurements on the same sheep.

\section{RESULTS}

\section{Long-Term Hyperglycemia and Hyperinsulinemia}

The ewes that received long-term infusions of glucose achieved a mean plasma glucose concentration $(85 \mathrm{mg} /$ $\mathrm{dL}$ ) that averaged 1.7 times their mean baseline value $(51$ $\mathrm{mg} / \mathrm{dL}$ ) and maintained plasma insulin concentrations $(141 \mu \mathrm{U} / \mathrm{mL})$ that averaged 6.7 times their mean baseline value $(21 \mu \mathrm{U} / \mathrm{mL})$. The ewes that received long-term infusions of insulin achieved and maintained plasma insulin concentrations $(55 \mu \mathrm{U} / \mathrm{mL})$ that averaged 2.75 times their mean baseline value $(20 \mu \mathrm{U} / \mathrm{mL})$; in these ewes, plasma glucose concentration $(26 \mathrm{mg} / \mathrm{dL})$ averaged $58 \%$ of their mean baseline value $(45 \mathrm{mg} / \mathrm{dL})$.

Maternal plasma concentrations of protein $C$, protein $\mathrm{S}$, factor $\mathrm{X}$, and AT-III were plotted against days of gestation in normal pregnant ewes. There was no significant correlation of protein concentration versus time from conception for protein $\mathrm{C}$, protein $\mathrm{S}$, factor X, ATIII, glucose, or insulin. There was no gestationally dependent variation in the plasma concentrations of any of these proteins. Table 1 displays results of glucose and insulin infusions on plasma concentrations of coagulation proteins in pregnant ewes. In comparison with the normal pregnant ewes, the ewes receiving glucose infusions were found to have decreases in plasma concentrations of protein C (29\%), protein S (17\%), and factor X (18\%), but not AT-III. The hypoglycemia/hyperinsulinemia model was associated with decreases in plasma concentrations of protein $\mathrm{C}$, protein $\mathrm{S}$, and factor $\mathrm{X}$, none of which achieved statistical significance.

Fetal plasma concentrations of protein $C$, protein $S$, factor X, and AT-III were plotted against days of gestation in the control fetuses. Correlation of protein concentration versus gestational age were not significant except for AT-III $(r=0.72)$. Only AT-III was found to be gestationally dependent in the fetal lamb.

Table 2 displays the fetal result of the long-term infusion studies. This model is different from the maternal model. Whereas the ewe became hyperglycemic and hyperinsulinemic as a result of glucose infusions, the fetuses of these ewes, overall, developed hyperglycemia with euinsulinemia. No fetal coagulation protein showed a mean effect of this degree of hyperglycemia alone. Four of the hyperglycemic fetuses responded to the maternal glucose infusion with at least a doubling of the fetal insulin concentration. These hyperinsulinemic fetuses exhibited a mean protein $C$ concentration that was $70 \%$ of the baseline concentration and differed from fetuses that were hyperglycemic but euinsulinemic $(p=0.014)$. The fetuses of the hypoglycemic, hyperinsulinemic ewes became hypoglycemic and hypoinsulinemic. These fetuses showed significant increases in concentrations of protein C, protein S, factor X, and AT-III.

Table 1. Maternal effects of long-term glucose or insulin infusions

\begin{tabular}{|c|c|c|c|c|c|c|c|c|c|c|c|}
\hline & \multicolumn{3}{|c|}{ Euglycemic/euinsulinemic } & \multicolumn{4}{|c|}{ Hyperglycemic/hyperinsulinemic } & \multicolumn{4}{|c|}{ Hypoglycemic/hyperinsulinemic } \\
\hline & $n$ & Mean & SD & $n$ & Mean & SD & $p$ & $n$ & Mean & SD & $p$ \\
\hline Protein $\mathrm{C}(\mathrm{U} / \mathrm{mL})$ & 157 & 97 & 20 & 32 & 69 & 28 & $<0.0001$ & 53 & 92 & 20 & 0.07 \\
\hline Protein $\mathrm{S}(\mathrm{U} / \mathrm{mL})$ & 109 & 104 & 17 & 31 & 86 & 19 & $<0.0001$ & 53 & 100 & 12 & 0.06 \\
\hline Factor $\mathrm{X}(\mathrm{U} / \mathrm{mL})$ & 109 & 108 & 20 & 31 & 89 & 37 & 0.004 & 52 & 103 & 19 & 0.12 \\
\hline AT-III $(\mathrm{U} / \mathrm{mL})$ & 32 & 104 & 10 & 23 & 105 & 15 & 0.88 & 19 & 105 & 9 & 0.73 \\
\hline Glucose $(\mathrm{mg} / \mathrm{dL})$ & 136 & 48 & 8 & 32 & 85 & 19 & 0.0000 & 52 & 26 & 11 & 0.0000 \\
\hline Insulin $(\mathrm{U} / \mathrm{mL})$ & 131 & 23 & 10 & 31 & 141 & 107 & 0.0000 & 52 & 55 & 19 & 0.0000 \\
\hline
\end{tabular}

Table 2. Fetal effects of long-term maternal glucose or insulin infusions

\begin{tabular}{|c|c|c|c|c|c|c|c|c|c|c|c|}
\hline & \multicolumn{3}{|c|}{ Euglycemic/euinsulinemic } & \multicolumn{4}{|c|}{ Hyperglycemic/euinsulinemic } & \multicolumn{4}{|c|}{ Hypoglycemic/hypoinsulinemic } \\
\hline & $n$ & Mean & SD & $n$ & Mean & SD & $p$ & $n$ & Mean & SD & $p$ \\
\hline Protein $\mathrm{C}(\mathrm{U} / \mathrm{mL})$ & 180 & 48 & 10 & 25 & 47 & 10 & 0.96 & 17 & 56 & 14 & 0.029 \\
\hline Protein S (U/mL) & 87 & 44 & 6 & 24 & 41 & 7 & 0.08 & 17 & 65 & 20 & 0.003 \\
\hline Factor $\mathrm{X}(\mathrm{U} / \mathrm{mL})$ & 87 & 24 & 10 & 24 & 22 & 6 & 0.19 & 16 & 31 & 5 & 0.0001 \\
\hline AT-III $(\mathrm{U} / \mathrm{mL})$ & 32 & 84 & 17 & 19 & 89 & 10 & 0.22 & 16 & 95 & 12 & 0.014 \\
\hline Glucose $(\mathrm{mg} / \mathrm{dL})$ & 116 & 16 & 4 & 25 & 33 & 10 & 0.0000 & 16 & 11 & 9 & 0.039 \\
\hline Insulin $(\mathrm{U} / \mathrm{mL})$ & 109 & 9 & 5 & 25 & 10 & 6 & 0.52 & 16 & 5 & 6 & 0.033 \\
\hline
\end{tabular}


Table 3 displays results of the long-term infusion studies on protein $\mathrm{C}$ using the full linear mixed effects model by group. The hyperglycemic/hyperinsulinemic group demonstrated a significant correlation between plasma concentrations of protein $\mathrm{C}$ and insulin. This group had achieved the highest concentration of insulin. Both hyperglycemic/hyperinsulinemic and hypoglycemic/hyperinsulinemic groups showed negative correlations between duration of glucose or insulin infusion and plasma concentration of protein $\mathrm{C}$. The most significant decrease in plasma protein $\mathrm{C}$ concentration was found in the glucose infusion group. Within each study group, however, there was no significant independent effect of glucose concentration per se on plasma protein $\mathrm{C}$ concentration.

Analyzing the full model by group, the differences among sheep accounted for a large portion of the variability found in the control and glucose infusion groups, but very little of the variability associated with the insulin infusion. Correlations between plasma concentrations of insulin and protein $C$ approached significance within the normal control ewes and their fetuses as seen in Figure 1. Approximately $12 \%$ of the variance in protein $\mathrm{C}$ concentration in the control pregnant ewes and fetuses can be accounted for by insulin concentration. The correlation between plasma concentrations of insulin and protein $\mathrm{C}$ was greatest in the glucose infusion group $(r=0.64)$.

Table 3 displays the analysis using the full model, combining all three groups into a single analysis. Plasma protein $\mathrm{C}$ concentration showed significant negative correlations with concentrations of both insulin and glucose; individual variability accounted for $36 \%$ of the variance. Insulin concentration yielded the strongest correlation.

\section{Short-Term Infusions of Glucose and Insulin}

Table 4 displays the mean maternal concentrations of protein $\mathrm{C}$ in the short-term study groups. There were no differences between the control animals receiving saline or somatostatin and saline. Therefore, these two groups were combined into one control group. Protein C concentrations were significantly lower in both the group receiving glucose infusions $(p=0.0002)$ and the group

Table 3. Significance of glucose, insulin, and duration of hypenglycemia and hyperinsulinemia on protein $C$ concentration

\begin{tabular}{llllll}
\hline & $n$ & Glucose & Insulin & Duration & $\begin{array}{c}\text { Subject } \\
\text { variability }\end{array}$ \\
\hline By group & 10 & NS & $p=0.05$ & $p=0.16$ & $50 \%$ \\
$\begin{array}{c}\text { Control } \\
\text { Euglycemic } \\
\quad \text { Euinsulinemic }\end{array}$ & & & & & \\
$\begin{array}{c}\text { Glucose infusion } \\
\text { Hyperglycemic } \\
\quad \text { Hyperinsulinemic }\end{array}$ & 7 & NS & $p=0.02$ & $p<0.001$ & $53 \%$ \\
$\begin{array}{c}\text { Insulin infusion } \\
\text { Hypoglycemic }\end{array}$ & 8 & NS & $p=0.07$ & $p=0.05$ & $0.2 \%$ \\
$\quad \begin{array}{l}\text { Hyperinsulinemic } \\
\text { Groups combined } \\
\text { All ewes }\end{array}$ & 25 & $p=0.01$ & $p=0.001$ & NS & $36 \%$ \\
\hline
\end{tabular}

receiving insulin infusions $(p=0.001)$ than in the combined control group. The study group that was made hyperglycemic/euinsulinemic by infusing glucose with somatostatin to suppress insulin release showed no decrease in protein $\mathrm{C}$ concentration over the $8-24 \mathrm{~h}$ of study.

Table 4 displays results for short-term fetal infusions. Although the short-term fetal infusions did not demonstrate differences in group means, five of seven fetuses that were given glucose infusions alone showed a decrease in protein $\mathrm{C}$ concentration of greater than or equal to $20 \%$, whereas only two of seven fetuses that received infusions of insulin alone showed a similar decrease in protein $\mathrm{C}$ concentration. Ewes and fetuses that exhibited a decrease in protein $C$ concentration with hyperinsulinemia with or without hyperglycemia showed a maximal effect at $4 \mathrm{~h}$.

\section{DISCUSSION}

The results of the present study provide strong evidence for an effect of hyperglycemia and hyperinsulinemia in pregnant and fetal sheep to decrease plasma protein $C$ concentration. First, there was a negative correlation between plasma insulin concentration and plasma protein $\mathrm{C}$ concentration in the control group of normal pregnant ewes and their fetuses that had normal range plasma concentrations of protein $\mathrm{C}$, glucose, and insulin. This would suggest that, under physiologic conditions, insulin may account for a small part $(12 \%)$ of the variability of protein $\mathrm{C}$ concentrations. This conclusion is further supported by experimental evidence from the pregnant ewes given long-term infusions of insulin that showed a significant negative correlation between protein $\mathrm{C}$ concentrations and the duration of hyperinsulinemia. Ewes given long-term infusions of glucose showed significant negative correlations between concentration of protein $\mathrm{C}$ and both insulin concentration and duration of hyperglycemia. When the study animals were analyzed by group, glucose was not shown to exert an independent effect on protein $\mathrm{C}$ concentration. When all of the animals were treated as one group, however, both plasma insulin and glucose concentrations contributed independently and negatively to protein $\mathrm{C}$ concentrations, with insulin exhibiting the dominant effect.

Vitamin K-dependent coagulation proteins, protein S and factor $\mathrm{X}$, showed similar but less significant decreases in plasma concentration during chronic hyperglycemia with hyperinsulinemia but no change with hyperinsulinemia alone. Plasma concentration of AT-III, a vitamin K-independent regulatory protein, showed no effect of hyperglycemia, hyperinsulinemia, or both in this model. These results do not exclude facilitative effects of hyperglycemia and hyperinsulinemia in decreasing synthesis as well as accelerating plasma disappearance of vitamin K-dependent proteins.

Based on these mixed results, short-term infusion studies were performed to isolate the individual effects of 


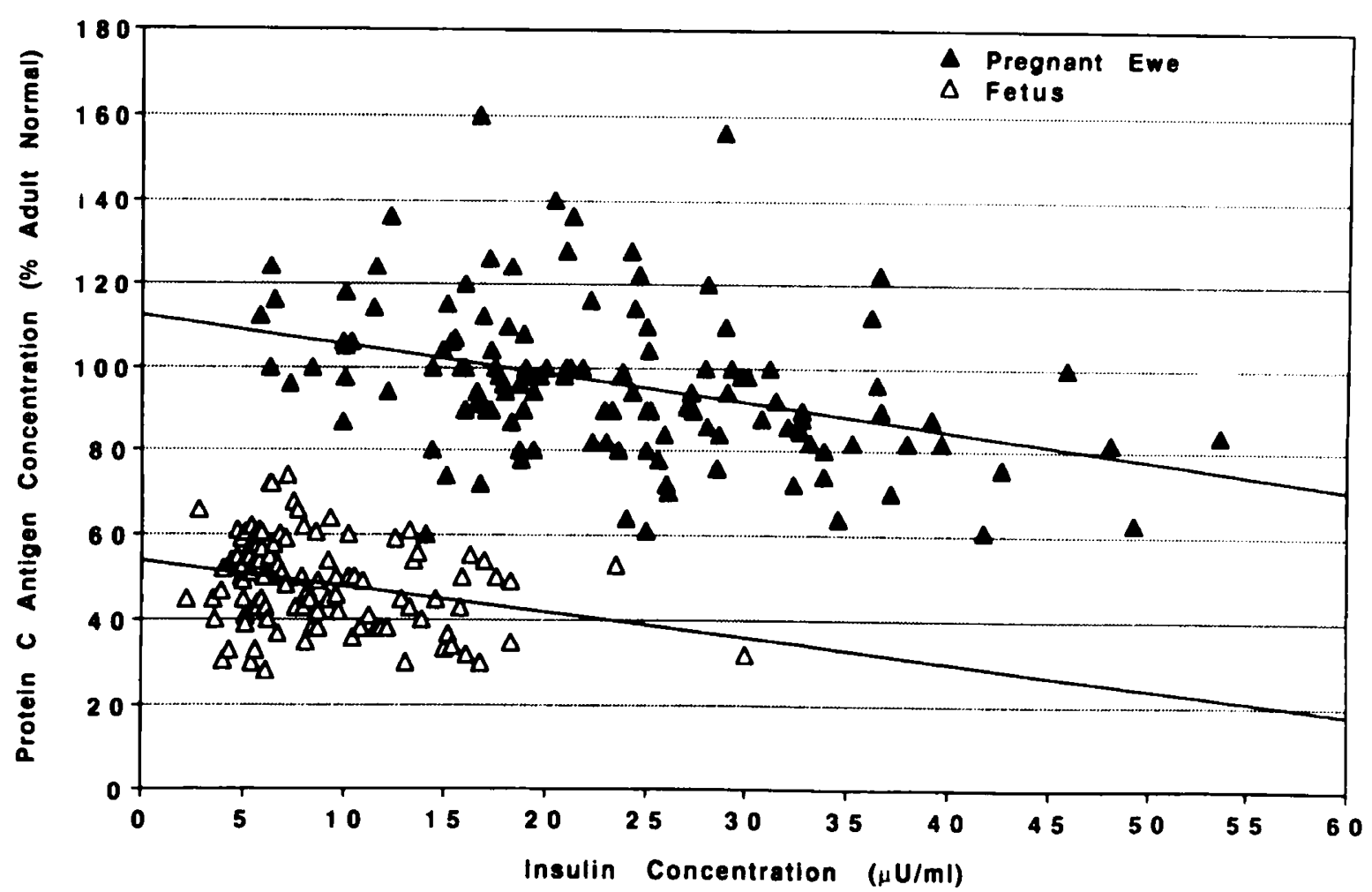

Figure 1. Correlation of protein $\mathrm{C}$ concentration with insulin concentration in normal pregnant ewes and their fetuses.

glucose and insulin on plasma protein $C$ concentration. In the pregnant ewes, insulin alone exhibited a negative effect on protein $\mathrm{C}$ concentration; hyperglycemia alone (insulin response was suppressed so that plasma insulin concentration was normal) showed no effect. In the fetus, protein $\mathrm{C}$ concentration was unresponsive to hyperglycemia or hyperinsulinemia alone. A facilitative or combined effect of hyperglycemia and hyperinsulinemia was suggested, similar to that found in the pregnant ewe. A partial explanation for the lesser effect of insulin in the fetus may relate to differences in fetal insulin sensitivity $(12,13)$, as well as reduced insulin response to glucose stimulation (17). The small number of studies and narrow range of gestational ages used in these short-term studies (predominantly 122-136 d) do not permit any conclusion regarding a potential developmental effect. In the longterm studies, the great decrease in protein $\mathrm{C}$ concentration and statistical significance of duration of study

Table 4. Effects of short-term infusions of glucose and insulin on plasma concentration of protein $C$

\begin{tabular}{lrrrr}
\hline \multicolumn{1}{c}{ Group } & $n$ & Mean & SD & $p$ \\
\hline Maternal & & & & \\
Control (saline \pm somatostatin) & 10 & 100 & 4.7 & \\
Glucose & 7 & 82 & 4.5 & $<0.01$ \\
Insulin and glucose clamp & 8 & 86 & 4.2 & $<0.01$ \\
Glucose and somatostatin & 2 & 106 & $\mathrm{~N} / \mathrm{A}^{*}$ & $\mathrm{NS}$ \\
Fetal & & & & \\
Control (saline \pm somatostatin) & 12 & 46 & 2.3 & \\
Glucose & 8 & 39 & 2.3 & $<0.01$ \\
Insulin and glucose clamp & 7 & 45 & 2.2 & $\mathrm{NS}$ \\
Glucose and somatostatin & 6 & 45 & 2.5 & $\mathrm{NS}$ \\
\hline
\end{tabular}

* N/A, not applicable. suggest that the effects of hyperinsulinemia and hyperglycemia on plasma concentrations of protein $C$ and other vitamin $\mathrm{K}$-dependent coagulation factors may be progressive with time.

In the fetal sheep, chronic hypoinsulinemia was associated with increased concentrations of protein $\mathrm{C}$, protein S, factor X, and AT-III. Data of Philipps et al. (18) suggest that insulin may act to decrease amino acid catabolism in the fetal sheep. Insulin effects on protein synthesis and net nitrogen accumulation are less certain (19-21). This study was not designed to estimate protein synthetic rates; no mechanism is suggested for the apparent opposite relationship between insulin and vitamin K-dependent protein concentrations.

Together, these data indicate that insulin exerts a negative effect on plasma concentrations of protein $\mathrm{C}$ and protein S. This effect may account for a part of the increased incidence of thromboses and apparent hypercoagulability in pregnant women with diabetes and their fetuses. Similar negative correlations have been reported between hyperglycemia and concentrations of protein $\mathrm{C}$ activity $(22,23)$. Vukovich and Schernthaner (22) described a decrease in the ratio of protein $\mathrm{C}$ to prothrombin activity and speculated that protein $\mathrm{C}$ activity may be decreased secondary to increased clearance rather than decreased hepatic synthesis. The investigations of Jones and Peterson (24) supported this speculation by documenting that heparin infusions reversed decreased fibrinogen survival during hyperglycemia. A single report of protein $\mathrm{S}$ in persons with well-controlled type I diabetes found decreased concentrations (25). Other investiga- 
tions of AT-III and protein $\mathrm{C}$ in diabetes have produced negative results (26-30). We did not find decreased ATIII chromogenic activity in our study. It may be that AT-III dysfunction is associated with chronic hypoinsulinemia or marked hyperglycemia, two conditions that were not part of our models.

The large number of clinical studies of persons with diabetes is confusing and does not yield unanimous conclusions regarding the effects of glucose and insulin on plasma concentrations of protein $\mathrm{C}$. The heterogeneity of the population of interest, as well as the labile plasma concentrations of glucose, insulin, and coagulation proteins, probably account for much of the variability of the results. However, the studies do show a strong trend toward hypercoagulability in persons with diabetes, with decreased plasma activity of anticoagulants and increased activity of procoagulants. The contributions of insulin and glucose cannot be isolated in the clinical studies, although altered protein function secondary to nonenzymatic glycosylation is suggested. The current ovine studies allow for control of the experimental variables and lend a stronger support to the probable role of insulin in the alteration of plasma concentrations of protein C. Furthermore, fetal and pregnant sheep have much lower basal and glucose-stimulated insulin secretion rates than humans. It is therefore reasonable to speculate that more marked effects of insulin on regulation of protein C circulating concentrations or plasma turnover may occur in human diabetics and their fetuses. Additional studies are indicated to further define the roles of insulin, glucose, and plasma protein $\mathrm{C}$ in the pathophysiology of thromboses and hypercoagulability in pregnant women with diabetes and their offspring.

Acknowledgments. The authors thank Gary O. Zerbe, Ph.D., and Ann Esler, Department of Biometrics, UCHSC, for statistical support and Dr. Rachelle Nuss for her critical comments.

\section{REFERENCES}

1. Oppenheimer EH, Esterly JR 1965 Thrombosis in the newborn: comparison between infants of diabetic and nondiabetic mothers. J Pediatr 67:549-556

2. Manco-Johnson MJ, Abshire TC, Jacobson LJ, Marlar RA 1991 Severe neonatal protein $\mathrm{C}$ deficiency: prevalence and thrombotic risk. J Pediatr 119:793-798

3. Clouse LH, Comp PC 1986 The regulation of hemostasis: the protein C system. N Engl J Med 314:1298-1303

4. Dahlbäck B, Carlsson M, Svensson PJ 1993 Familial thrombophilia due to a previously unrecognized mechanism characterized by poor anticoagulant response to activated protein $C$ : prediction of a cofactor to activated protein C. Proc Natl Acad Sci USA 90:10(0)4-1008

5. Griffin JH, Evatt B, Wideman C, Fernández JA 1993 Anticoagulant protein C pathway defective in majority of thrombophilic patients. Blood 82:1989-1993

6. Hartman KR, Manco-Johnson MJ, Rawlings JS, Bower DJ, Marlar RA 1989 Homozygous protein $C$ deficiency: early treatment with warfarin. Am J Pediatr Hematol Oncol 11:395-401

7. Mahasandana C, Suvatte V, Chuansumrit A, Manco-Johnson MJ, Jacobson L. Hathaway WE 1990 Homozygous protein S deficiency in an infant with purpura fulminans. J Pediatr 117:750-753

8. Kisker CT, Robillard JE, Clarke WR 1981 Development of blood coagulation: a fetal lamb model. Pediatr Res 15:1045-1050

9. Massicotte P, Mitchell L, Andrew M 1986 A comparative study of coagulation systems in newborn animals. Pediatr Res 20:961-965

10. Moalic P, Gruel Y, Foloppe P, Delahousse BB, LeClerc M, Leroy J 1989 Hemostasis development in the lamb fetus and neonate. Am J Vet 50:59-63

11. Manco-Johnson M, Nuss R 1992 Protein C concentrate prevents peripartum thrombosis. Am J Hematol 40:69-70

12. Hay WW Jr, Meznarich HK 1986 The effects of hyperinsulinemia on glucose utilization and oxidation and on oxygen consumption in the fetal lamb. Q J Exp Physiol 71:689-698

13. Hay WW Jr, Sparks JW, Gilbert M, Battaglia FC, Meschia G 1984 Effect of insulin on glucose uptake by the maternal hindlimb and uterus, and by the fetus in conscious pregnant sheep. J Endocrinol 10():119-124

14. Wilkening RB, Meschia G 1983 Fetal oxygen uptake, oxygenation and acidbase balance as a function of uterine blood flow. Am J Physiol 13:H749-1 755

15. Marconi AM, Battaglia FC, Meschia G, Sparks JW 1989 A comparison of amino acid arteriovenous differences across the liver and placenta of the fetal lamb. Am J Physiol 257:E909-E915

16. Laird NM, Ware JH 1982 Random effects model for longitudinal data. J Biometrics 38:963-974

17. Phillips AF, Carson BS, Meschia G, Battaglia FC 1978 Insulin secretion in fetal and newborn sheep. Am J Physiol 235:E467-E474

18. Phillips AF, Rosenkrantz TS, Lemons JA, Knox I, Porte PJ, Raye JR 1990 Insulin-induced alterations in amino acid metabolism in the fetal lamb. J Dev Physiol 13:2251-2259

19. Philipps AF, Dubin JW, Raye JR 1980 Alanine-stimulated insulin secretion in the fetal and neonatal lamb. Am J Obstet Gynecol 136:596-602

20. Wilkening RB, Boyle DW, Teng C, Meschia G, Battaglia FC 1994 Amino acid uptake by the fetal ovine hindlimb under normal and euglycemic hyperinsulinemic states. Am J Physiol 266:E72-E78

21. Liechty EA, Boyle DW, Moorehead H, Liu YM, Denire SC 1992 Effect of hyperinsulinemia on ovine fetal leucine kinetics during prolonged maternal fasting. Am J Physiol 263:E696-E7()2

22. Vukovich TC, Schernthaner G 1986 Decreased protein $C$ levels patients with insulin-dependent diabetes mellitus. Diabetes 35:617-619

23. Ceriello A, Quatraro A, Dello Russo P, Marchi E, Barbanti M, Milani M, Giugliano D 1990 Protein $C$ deficiency in insulin-dependent diabetes: a hyperglycemia-related phenomenon. Thromb Haemostasis 64:104-107

24. Jones RL, Peterson CM 1981 Hematologic alterations in diabetes mellitus. Am J Med 70:339-352

25. Schwarz HP. Schernthaner G, Griffin JH 1987 Decreased plasma levels of protein $S$ in well-controlled type I diabetes mellitus. Thromb Haemostasis 57:240

26. Carssi F, Morale M, Puccetti R 1992 Coagulation and fibrinolytic system impairment in insulin dependent diabetes mellitus. Thromb Res 67:643-654

27. Patrassi GM, Picchinenna R, Vettor R, Cappellato G, Coccarielli D, Girolami A 1985 Antithrombin III activity and concentration in diabetes mellitus. Thromb Haemostasis 54:415-417

28. Vigano S, Mannucci PM, D’Angelo A, Golfi C, Gensini GF, Rostagno C, Neri Serneri GG 1984 Protein $C$ antigen is not an acute phase reactant and is often high in ischemic heart disease and diabetes. Thromb Haemostasis 52:263-266

29. Marongiu F, Conti M, Mamelia G, Sorano GG, Cossu E, Cirillo R, Balestrieri A 1990 Is the imbalance between thrombin and plasmin activity in diabetes related to the behaviour of antiplasmin activity? Thromb Res 58:91-99

30. Biondi G, Sorano GG, Conti M, Mameli G, Cirillo R, Marongiu F 1991 The behavior of protein $C$ in diabetes is still an open question. Thromb Haemostasis $66: 267$ 